\title{
Philosophy of Life Development: A Preventive Effort for Aggressive Behavior
}

\author{
Fadhilla Yusri ${ }^{1}$, Yeni Afrida ${ }^{2}$ \\ \{fadhillayusri@gmail.com ${ }^{1}$, yeniafrida664@gmail.com ${ }^{2}$ \} \\ Faculty of Education and Teacher Training, Institut Agama Islam Negeri (IAIN) Bukittinggi, West \\ Sumatera, Indonesian ${ }^{1,2}$
}

\begin{abstract}
Aggressive behavior occurs among adolescents, especially in middle and high school students. This issue is very concerned matter. Adolescents need to develop the philosophy of life. Thus, adolescents can control their behavior. The purpose of this study is development of a philosophy of life through guidance and counseling services as a preventive effort for the aggressive behavior of bullying. This research is an experimental study with a pre-experimental design. The results of this study indicate the service information is effective to develop adolescent life philosophy in order to reduce aggressive behavior of students.
\end{abstract}

Keywords. aggressive behavior, bullying, counseling and philosophy of life

\section{Introduction}

Aggression behavior of adolescents is increasing from year to year. Aggressive students do not hesitate to attack and harm others. Adolescents must get their needs in order to fulfill their desire. Adolescent desires are instinctively. It is crucial for their identity and fulfill the task of adolescent self-development [1]. Adolescents need a philosophy of life. This is the need of adolescents to obtain a set of values and ethical systems as a guide for behavior [2]. Teenagers have an interest about truth, religion and ideal values that apply in the society [3]. If the need for philosophy of life is fulfilled in adolescents, adolescents will have good selfcontrol. Adolescent will learn about the truth and norms of life in society due to the need for a philosophy of life. It can be developed through education. Teenagers are taught about basic moral guidelines that can prevent them from behaving immorally, self-injury, etc [4]. Moral values are important to learn during the education. Guidance and counseling services are the way to get the philosophical needs of adolescent. The religious moral beliefs positively associated with the level of perception the family relationship-acceptance, but negatively associated with the level of anxiety, depressiveness, aggressiveness, with the addictive behaviors and the level of perception of the family relationships: rejection and control [5]. If adolescents do not get their needs in minimum level, they will experience delays in achieving development. Adolescents even show abnormal behavior. Adolescents can maintain their aggressive behavior, if their needs are not encountered [3]. Aggressive behavior is closely related to bullying. It is common among students now days. Dynamics of age development of crisis periods; the analysis of psychological, social and clinical components of agressive dehaviour, social functioning, estimation of behaviour and motivation of criminally significant 
period at fulfilment of socially dangerous act[6]. Aggression is a situation when someone obtains something in force. However, dominance over the target or victim is incidental and unintentional, while bullying is the final condition through the use of force to hurt others and to show dominance over others [7].

Bullying is a very familiar behavior in the public. The impact of bullying is very concerning. Bully is defined as intentionally behaviors that cause physical and psychological damage to the victims [8]. Daradjat said that everyone has needs and they need to get it[9]. If they cannot get the needs, it will be a shock. It is also a problem for adolescents in order to search for identity. If adolescent does not get their needs, aggressive behavior is one of the issue such as bullying. Both of these actions can have an overwhelming impact on the victim even deep trauma. Kasih Bundo Community Learning Activity Center (PKBM) is one of nonformal educational institutions in Bukittinggi. This educational institution organizes a school in some packages such as A package, B package and $\mathrm{C}$ package. This educational institution organizes 345 students with the range of ages from 7 to 21 years old. Based on the results of Yusri and Jasmienti, aggressive behavior in the PKBM Kasih Bundo can be categorized as high with a percentage of $74.4 \%$ [10]. The formulation of the problem in this study is about the effectiveness of information services to develop the philosophy of adolescent life in order to reduce aggressive behavior of bullying. The study was conducted at PKBM Kasih Bundo, Bukittinggi. The study aims to determine the effectiveness of the service information to develop adolescents' philosophy of life in reducing aggressive of bullying. The hypothesis in this study is:

Ha: information services to develop a philosophy of adolescent life are effective in reducing aggressive behavior in bullying.

Ho: Information services to develop the philosophy of adolescent life are not effective in reducing the aggressive behavior in bullying.

\section{Methodology}

This research is an experimental study with a pre-experimental design. This study uses a group pretest posttest design model that is designed to only contain a group experiment without involving the comparison group [11]. The design of this study focuses on the difference between pretest and posttest as a result of treatment. This study aims to measure the effect of the treatment on the dependent variable. The populations in this study were the students of PKBM Kasih Bundo, Bukittinggi, with a total of 345 people. Determination of the sample in this study used non random sampling techniques [12]. Not all students can be an informant. There are 60 people who are indicated to behave aggressively and to carry out bullying. The data is analyzed by Likert measurement scale. The scale data is designed by the researcher due to validity and reliability. The validity of the research instrument was obtained by conducting expert judgment. The reliability of the research instrument was obtained by analyzing the results of the instrument trials on respondents who had the same characteristics as the sample. It is a valid measurement scale item that will be used to reveal respondents' data in the study. Data processing of the results of the pretest and posttest using simple statistics. In order to focus on the effectiveness of the treatment in the study, the data results were processed using different tests such as t-test. The research was conducted in three steps such as:

1. The researcher conducted a pretest to measure the initial condition of the respondent before treatment 
2. Researchers do treatment in information services to improve the philosophy of life with media visual and audio visual equipment

3. Researchers conducted posttest to identify the state of the dependent variable after treatment.

\section{Result}

The results of the research focus on the effectiveness of information services to develop the philosophy of adolescent life in reducing aggressive behavior that causes bullying..

\subsection{Pretest description of students' aggressive behavior}

Table 1. Pretest description of PKBM student aggression behavio $\mathrm{N}=60$

\begin{tabular}{|c|c|c|c|c|c|c|c|}
\hline \multirow[t]{3}{*}{ No } & \multirow{3}{*}{$\begin{array}{l}\text { Aspects of } \\
\text { Aggressive } \\
\text { Behavior }\end{array}$} & \multicolumn{6}{|c|}{ Descriptive Statistics } \\
\hline & & \multicolumn{2}{|l|}{ Mean } & SD & Range & \multicolumn{2}{|c|}{ Skor } \\
\hline & & Skor & $\%$ & & & Min & Max \\
\hline 1 & Physical & 4,3 & 83,9 & 1,0 & 4,3 & 0,6 & 5 \\
\hline 2 & $\begin{array}{l}\text { Aggression } \\
\text { Verbal } \\
\text { Aggression }\end{array}$ & 4,2 & 81,9 & 1,0 & 3,1 & 0,15 & 5 \\
\hline 3 & Anger & 3,5 & 69,8 & 1,3 & 5 & 0 & 5 \\
\hline 4 & Hostility & 3,6 & 71,1 & 1,3 & 4,2 & 0,7 & 5 \\
\hline \multicolumn{2}{|c|}{ Average } & 3,9 & 76,6 & 1,1 & 4,1 & 0,3 & 5 \\
\hline
\end{tabular}

Based on the data, the aggressive behavior of the Kasih Bundo in Bukittinggi students is categorized as high. The average percentage score of $76.6 \%$ with SD 1.1. The highest score is in the aspect of physical aggression with a percentage of $83.9 \%$ and SD 1 . While the lowest score is in the aspect of anger with a percentage of $69.8 \%$ and SD 1.3. Aggressive behavior that is widely practiced by PKBM Kasih Bundo students is aggressive physical-related behavior such as slapping, throwing, kicking, hitting and other forms of physical aggressive behavior. While aggressive behavior that sometimes arises among the students of PKBM Kasih Bundo is anger or anger, such as anger, resentment, annoyance, temperamental and difficult to control emotions. Kasih Bundo student showed aggressive behavior in daily life at the institution.

\subsection{Posttest description of students' aggressive behavior}

Table 1. Post test description of aggression behavior of PKBM students N-60

\begin{tabular}{|c|c|c|c|c|c|c|c|}
\hline \multirow[t]{3}{*}{ no } & \multirow{3}{*}{$\begin{array}{l}\text { Aspects } \\
\text { Aggressive } \\
\text { Behavior }\end{array}$} & \multicolumn{6}{|c|}{ Descriptive Statistics } \\
\hline & & \multirow{2}{*}{$\begin{array}{l}\text { Mean } \\
\text { Skor }\end{array}$} & & \multirow[t]{2}{*}{ SD } & \multirow[t]{2}{*}{ Range } & \multicolumn{2}{|c|}{ Skor } \\
\hline & & & $\%$ & & & Min & $\operatorname{Max}$ \\
\hline 1 & $\begin{array}{l}\text { Physical } \\
\text { Aggression }\end{array}$ & 1,8 & 34,2 & 1,1 & 4,3 & 0,6 & 5 \\
\hline 2 & $\begin{array}{l}\text { Verbal } \\
\text { Aggression }\end{array}$ & 1,8 & 34,3 & 1,0 & 3,1 & 0,15 & 5 \\
\hline 3 & Anger & 2,3 & 42,2 & 1,3 & 5 & 0 & 5 \\
\hline 4 & Hostility & 2,2 & 41,1 & 1,3 & 4,2 & 0,7 & 5 \\
\hline \multicolumn{2}{|c|}{ Average } & 2,02 & 37,9 & 1,1 & 4,1 & 0,3 & 5 \\
\hline
\end{tabular}


Based on the data, the aggressive behavior of the PKBM Kasih Bundo students can be categorized as low after being treated. The data show the average score of 37.9 with SD 1.1. The lowest aggressive behavior practiced by PKBM Kasih Bundo students after treatment was physical aggression with a percentage of $34.2 \%$ and SD 1.1 . While actions that are sometimes still often practiced are aggressive anger behavior with a percentage of $42.2 \%$ and SD 1.3. After being given treatment, aggressive behavior in the physical aspects which is initially the most practiced by students is the lowest practiced by students. While aggressive behavior that still needs to be improved in its practice at the PKBM Kasih Bundo is anger, because it is still often practiced in the lives of students at PKBM Kasih Bundo. Thus, the aggressive behavior carried out by the PKBM Kasih Bundo students had rarely exposed in daily life.

\subsection{Difference Test Results (t-test)}

Table 1. A description of the different aggression behavior of student $\mathrm{N}=60$

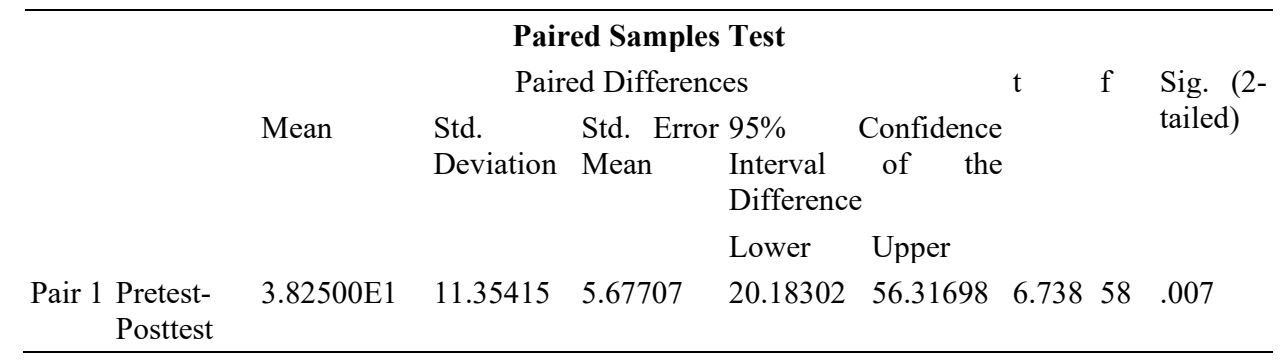

Based on the data, the probability (Sig. 2-tailed) of aggressive behavior of PKBM Kasih Bundo students is 0.007 or probability below alpha $0.05(0.007<0.05)$. If $\mathrm{p}$ is smaller than $\alpha$, there is a significant decrease in aggressive behavior of students after information service activities to develop the philosophy of adolescent life. Based on these results, $\mathrm{H}_{0}$ is rejected and $\mathrm{H}_{\mathrm{a}}$ is accepted. The service information is effective to develop adolescent life philosophy in order to reduce aggressive behavior of students in Kasih Bundo. Providing continuous information services with materials related to the development of life philosophy and the appearance of harmful aggressive behavior videos, has a good impact on reducing the aggressive behavior of students.

\section{Discussion}

Based on the results, there is an aggressive behavior of students in Kasih Bundo as at high category with an average score of 76.7 and SD 1.1 before treatment information services to develop a philosophy of life adolescent. It is commonplace for students to display hurtful behavior for individuals who are weaker in daily life of Kasih Bundo institutiont. Aggressive behavior is a common thing in different situations in Kasih Bundo institutions. In general, aggressive behavior that appears is physical violence, attacking friends by using physical force such as slapping, hitting, kicking, scratching, pinching, and fighting. The code of conduct in the PKBM Kasih Bundo cannot be applied as tightly as in a formal school, because it will have an impact on the reduced number of students who wish to continue their education at the nonformal educational institutions. In addition to the weak implementation of discipline in the 
PKBM Kasih Bundo, the surrounding environment also had an influence on the development of aggressive student behavior, one of which was a friend. In general, students studying at the Kasih Bundo PKBM are students who have been expelled from school due to various violations they have committed. It can be said that in the PKBM Kasih Bundo students had gathered at the school that had previously experienced problems both related to violations of discipline or those related to etiquette. There is a significant relationship between having aggressive friends and developing aggressive behavior [13]. Aggressive behavior is not only originating from individuals, but it also influenced by the environment. Influenced potential factors are aggressive behavior from peers and social characteristics [14]. Aggressive behavior by students of Kasih Bundo after being given information service treatment was in the low category with an average score of 37.9 and SD 1.1. The philosophy of life as one of the needs of adolescents can influence the students' behavior. Information service treatment about the philosophy of life can suppress the aggressive behavior of adolescents. It focuses on the values of truth and rules of adolescents. In general, teens are curious about all the rules and norms that apply in the community. Teenagers need other people to give them an understanding of the rules of truth that apply in society. They have desire to explore a philosophy of life [15]. Teenagers began to be interested about truth, religion and ideal values. Moral as part of the philosophy of adolescent life can be educated by giving examples, defining, discussing, playing roles and giving gifts to students who behave according to rules [16]. If adolescent's need for a philosophy of life is fulfill, then the teenager will feel comfortable and calm.

Different test results showed that the probability (Sig. 2-tailed) of the aggressive behavior of Kasih Bundo students was 0.007 or probability below alpha $0.05(0.007<0.05)$. This means that if $\mathrm{p}$ is smaller than $\alpha$, then there is a significant decrease in aggressive behavior of students after information service activities. There is a significant difference between the pretest and posttest results of the aggressive behavior of students in the Kasih Bundo. After being given intensive treatment to Kasih Bundo PKBM students, it can be seen that the intensity of the emergence of aggressive behavior is decreasing. This proves that students really need information about the philosophy of life that applies in the midst of society. During this time maybe no one has provided detailed information to students about the truth values that apply in society. So that when they get it it has a direct impact on controlling their behavior, in the form of a decrease in the intensity of the occurrence of aggressive behavior[17].

In order to fulfill the needs of philosophy of life, providing information about the value of truth in life through a variety of related subjects is the best way [3]. Providing information services is one way that can be done to help provide understanding to students about the values of truth in the lives they need. Teachers, parents and adults in general are responsible for giving teenagers an understanding of the philosophy of life. Therefore, friends can also be involved to instill a philosophy of life in adolescents. Peers can discuss about their need for a philosophy of life. Children who only have aggressive friends will tend to be aggressive, while children who have humble friends will tend to be more humble [18]. Peer discussion will help teenagers to review the need for their philosophy of life because it is easier to identify the needs for their age ranges. In addition, the use of guidance and counseling services through information services can also be used to develop a philosophy of life in adolescents. 


\section{Conclusion}

Information services about philosophy of adolescent are an effective way to reduce the aggressive behavior of bullying. Moral as part of the philosophy can be trained by giving examples, defining, discussing, playing roles and giving gifts to good students [16]. Choosing a good friend can also influence the level of aggressive behavior. Children who only have aggressive friends will tend to be aggressive, while children who have humble friends will tend to be more humble [18]. Providing information services and choosing the right friends can suppress the aggressive behavior that causes bullying among adolescents.

\section{Acknowledgment}

The author would like to thank the elements of the leadership, employees and students of PKBM Kasih Bundo who have helped many writers in this study. The author also thanks the research team who have worked together to do this research. The author also thanks all parties who contributed to the smooth running of this research.

\section{References}

[1] S. R. Monks, F. J; Knoers, A.M.P; Haditono, Developmental Psychology. (Psikologi Perkembangan). Yogyakarta: UGM PRESS, 2006.

[2] M. Ali, M; Asrori, Adolescent Psychology: Student Development. Jakarta: Bumi Aksara, 2014.

[3] Prayitno E; Erlamsyah, Psychology of Youth Development (Psikologi Perkembangan Remaja). Padang: UNP Press, 2002.

[4] Santrock Jhon W, Adolescence (Remaja). Jakarta: Erlangga, 2007.

[5] M.Hasanovica; A.Hodicb; S.Hodicc; I.Pajevica., "The Association of the Religious Moral Beliefs, Anxiety, Depressiveness, Agressiveness, Family Relations and Addictive Behaviors of the School Adolescents in the Postwar Bosnia-Herzegovina," Eur. Psychiatry, vol. Volume 30., no. Supplement 1, p. 496.

[6] E. V. Makushkin and V. D. Badmaeva, "Criminal agressive-violent and gomcidal behaviour of children and adolescents," Eur. Psychiatry, vol. Volume 22, no. Supplement 1, p. Pages S309S310.

[7] E. B. Hurlock, Developmental psychology: An approach throughout life span. (Psikologi perkembangan, suatu pendekatan sepanjang rentang kehidupan). Jakarta: Erlangga, 1996.

[8] D. Smith, P.K. \& Thompson, Practical approaches to bullying. London: David Fulton, 1991.

[9] Zakiah Darajat, Psikoterapi Islam. Bandung: Eresco, 2002.

[10] Yusri F; Jasmienti, “The Effect of Adolescent's Needs on Aggressive Behavior of Students in Kasih Bundo. (Pengaruh Pemenuhan Kebutuhan Remaja Terhadap Perilaku Agresif Siswa Di PKBM Kasih Bundo Kota Bukittinggi).,” J. Islam Realita, vol. Vol. 1, No, pp. 79-91, 2017.

[11] Sarwono J, Quantitative \& Qualitative Research Methods. (Metode Penelitian Kuantitatif \& Kualitatif). Yogyakarta: Graha ilmu, 2006.

[12] Sugiyono, Educational Research Method. (Metode Penelitian Pendidikan). Bandung: Alfabeta, 2013.

[13] P. M. Brechwald WA, "Beyond homophily: A decade of advances in understanding peer influence processes.," J. Res. Adolesc., vol. 21: DOI: 1, no. (1), pp. 166-179., 2011.

[14] M. L. Cillessen AH, "From censure to reinforcement: Developmental changes in the association between aggression and social status.," Child Dev., vol. 75. DOI: 1, no. (1), pp. 147-163, 2004.

[15] Mappiare, Adolescent Psychology. (Psikologi Remaja). Surabaya: Usaha Nasional, 2002.

[16] Santrock Jhon W, Adolescence. Jakarta: Erlangga, 2003. 
[17] R. A. Cillessen AH, "Understanding popularity in the peer system. Current Directions in Psychological Science.," Child Dev., vol. 14. DOI: 1, no. (2), pp. 102-105, 2005.

[18] dkk Henneberger, "The Effect of Having Aggressive Friends on Aggressive Behavior in Childhood: Using Propensity Scores to Strengthen Causal Inference,” J. Soc Dev, vol. 26. doi:10, no. (2), pp. 295-309, 2017. 